\title{
Construction of Enriched Resource for Primary Therapeutic Targets of Approved and Clinical Trial Drugs
}

\author{
Hong Yang, Chunyan Yu, Yinghong Li, Feng Zhu* \\ School of Pharmaceutical Sciences, Chongqing University, Chongqing, China \\ Email: *zhufeng@cqu.edu.cn
}

How to cite this paper: Yang, H., Yu, C.Y., Li, Y.H. and Zhu, F. (2017) Construction of Enriched Resource for Primary Therapeutic Targets of Approved and Clinical Trial Drugs. Journal of Biosciences and Medicines, 5, 1-6.

https://doi.org/10.4236/jbm.2017.53001

Received: January 6, 2017

Accepted: March 7, 2017

Published: March 10, 2017

\begin{abstract}
An assessment of the efficacy targets of drugs that represent an opportunity for targeted therapy is fundamental to the development of post-genomic research strategies within the pharmaceutical industry. Identification and validation of efficacy target is an important process in drug discovery and development. Extensive drug discovery efforts have yielded many approved and candidate drugs. Although sever drug databases provide the drug and their corresponding targets, there is an insufficient coverage of the clinical trial drugs over the past decades. Here, we conduct a comprehensive survey for current clinical trial drugs, therapeutic targets. The analysis contents include: 1) collect clinical trial drugs from different sources, 2) By analysis of the literature, we summarize the criteria for assign therapeutic targets for each drug based on its indication. The knowledge of these drugs and their targets is useful not only for drug discovery and development of targeted therapy, but also for facilitating the discovery of systems pharmacology.
\end{abstract}

\section{Keywords}

Drug, Drug Target, Indication, Protein Target of a Drug, Target of Disease

\section{Introduction}

The development of current biopharmaceutical industry [1] [2] [3] have led to the discovery and clinical testing of thousands of targeted agents, and the approval of a large quantity of drugs to treat or diagnose a disease. These agents exert their clinical effect(s) by modulating a molecular structure (chemically definable by at least a molecular mass) in different biological and disease regulatory pathways [2]. The knowledge of these agents, their efficacy targets not only can be filled with numerous hurdles that call for targeted therapeutics [4] [5], 
but also for assisting the research of systems pharmacology [6] [7] designed at the discovery of multi-target drugs [8] and drug combinations [9].

While there is an inadequate coverage of the number and the detailed information of clinical trial drugs in the established drug [10], efficacy target [11], pharmacology [12], bioactive compound [13], binding [14], and pathway [15] databases (Table 1). The shortage of the clinical trial drugs in these databases can be further revealed by the reported drug clinical trial success rates. For instance, among these databases, the previous version of the Therapeutic Target Database (TTD) contains the largest set of 3147 clinical trial drugs vs. 2003 approved drugs. The ratio of the approved and clinical trial drugs is $63.6 \%$, which is much larger than the reported $6.6 \%-13.4 \%$ phase I clinical trial to drug approval success rates [16]. The update of Therapeutic Target Database (TTD) in 2016 increases markedly current and discontinued clinical trial drugs searchable from the literatures, public reports and clinical trial websites [17], which can be proven by the number of targets have been reported in 2006 based on the number of innovative targets rates in 2002.

\section{Collection of Approved and Clinical Trial Drugs}

Approved drugs and clinical trial drugs represent special classes of therapeutic agents in advanced development stages, the knowledge of these agents, their therapeutic targets is significantly important for accelerating the future drug research and development. Hence, there is a strong need to enlarge the coverage of the clinical trial drugs, targets. In our analysis, the primary targets and their corresponding drugs/agents were initially collected from the company websites and publications or review articles in reputable journals (e.g. Journal of Neurochemistry, Current Opinion in Pharmacology, Drug Discovery Today, Nature Reviews Drug Discovery, Current Topics in Medicinal Chemistry, Science, Clinical

Table 1. Examples of well-known drug target database.

\begin{tabular}{|c|c|c|}
\hline $\begin{array}{c}\text { Name of } \\
\text { drug database }\end{array}$ & Description & $\begin{array}{c}\text { Number of } \\
\text { clinical trial drugs }\end{array}$ \\
\hline DrugBank [10] & $\begin{array}{c}\text { A bioinformatics and cheminformatics resource } \\
\text { combining detailed drug data with comprehensive } \\
\text { drug target information }\end{array}$ & 1130 \\
\hline $\begin{array}{l}\text { TTD [11] } \\
\text { Therapeutic target } \\
\text { database }\end{array}$ & $\begin{array}{l}\text { A database providing information about } \\
\text { known and explored therapeutic protein } \\
\text { and nucleic acid targets, and their drugs }\end{array}$ & 3147 \\
\hline $\begin{array}{l}\text { GtoPdb [12] } \\
\text { Guide to } \\
\text { PHARMACOLOGY }\end{array}$ & $\begin{array}{l}\text { An online, open-access portal to } \\
\text { pharmacological information on } \\
\text { all the human targets of prescription drugs }\end{array}$ & 493 \\
\hline $\begin{array}{l}\text { ChEMBL [13] } \\
\text { ChEMBL bioactivity } \\
\text { database }\end{array}$ & $\begin{array}{l}\text { An Open Data database containing binding, } \\
\text { functional and ADMET information for } \\
\text { a large number of drug-like bioactive compounds. }\end{array}$ & 676 \\
\hline BindingDB [14] & $\begin{array}{c}\text { A database of experimentally } \\
\text { determined protein-ligand binding affinities }\end{array}$ & 0 \\
\hline KEGG [15] & $\begin{array}{l}\text { A collection of databases dealing } \\
\text { with genomes, biological pathways, } \\
\text { diseases, drugs, and chemical substances }\end{array}$ & 0 \\
\hline
\end{tabular}


Colorectal Cancer, and so on), PhRMA report of Medicines for diabetes, neurological disorders, HIV/AIDS, cancer, children, and rare diseases during 20092015, which explicitly mentioned the targets and theirs corresponding drugs, and the 2014-2015 drug pipeline reports from the websites and annual reports of 183 pharmaceuticals companies (e.g. Abbott, Bayer, Boehringer Ingelheim, Merck, Eli Lilly, Novartis, Pfizer, Roche, Sanofi, Takeda Pharmaceutical, GlaxoSmithKline, and so on). This procedure gave rise to 9528 clinical trial drugs and 2097 approved drugs by FDA in update of TTD [17].

\section{Identification of the Primary Therapeutic Target(s)}

Identification of the targets for approved drugs, drugs in clinical trial, and experimental agents is the most critical job. In order to identify the primary efficacy targets through which the drug mediates its clinical therapeutic activities, a comprehensive analysis of the literature for each drug is needed. The criteria for assignment were strict in that strong evidence of cell-based and/or in vivo evidence linking the target (and specific target subtype) to the effect of the drug must exist alongside binding data [1] [18]. Other criteria for potential drug targets must be related to the corresponding disease tested in clinic (Figure 1). For monoclonal antibodies or recombinant proteins/peptides, their efficacy target(s) are relatively easy to assign because of their specificity.

The literature is often complex in terms of the information provided about efficacy targets. For cases in which a specific target is believed to be the sole or major route through which a drug achieves its efficacy, we accurately identified the drug against the single target at specific protein/mRNA subtype level, such as HER2 targeted by trastuzumab and mRNA of ApoB-100 targeted by mipomersen. For multi-target drugs, their targets were tentatively divided into the primary efficacy targets (play essential roles in the targeted disease) and the secondary targets (play facilitating roles such as drug bypass signaling in the disease). In the latest version of TTD, only the primary efficacy targets were identified and assigned as drug target. For example, INCB018424 is a dual inhibitor of

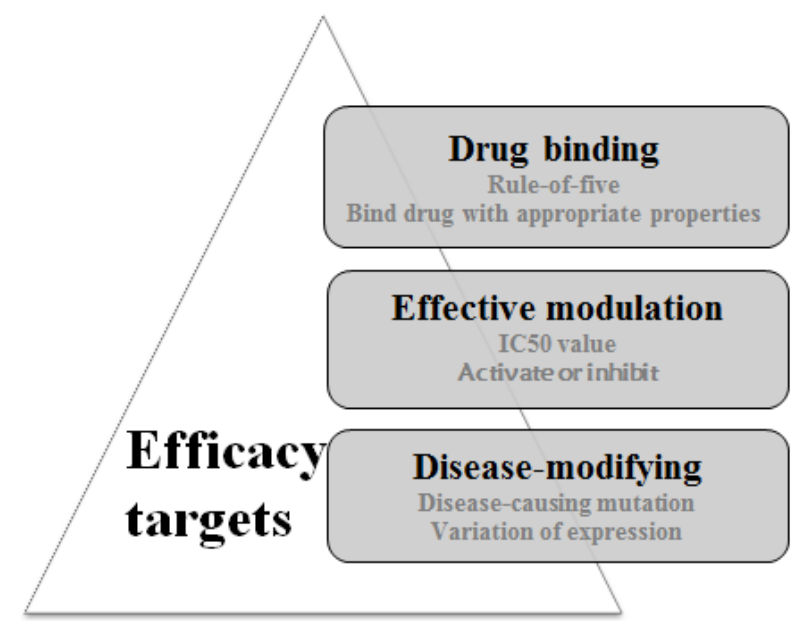

Figure 1. Criteria for assignment of therapeutic targets. 
both JAK1 and JAK2. About half of patients with myelofibrosis carry a gain-offunction mutation (V617F) in JAK2 gene that is the major contributor to the pathophysiology of this disease [19]. Thus, only JAK2 was identified as the primary efficacy target of INCB018424. Other than those targets of well-defined subtype, the remaining can be group into three categories. Firstly, some are imprecisely defined as targets with ambiguous subtype/subunit. For example, it is difficult to identify the specific target subtype/subunit for benzocaine, therefore the sodium channel was assigned as target of this drug. Secondly, for cases in which targets are imprecisely defined as target with ambiguous target species. These targets are especially for infection related diseases. For example, teicoplanin is an antibiotic treating broad spectrum bacterial infections by inhibiting bacterial cell wall synthesis. Thirdly, the others targets are imprecisely defined as only to the pathway/biological process level. For example, the mode of action of tecfidera [20] is not clear so far. However, it was reported that this drug exerts its therapeutic effect by activating NRF2 pathway, thus, NRF2 pathway is imprecisely assigned as tecfidera's target.

There is a relatively small, but clinically significant, class of drugs that bind to DNA, or that have no an unknown or distinct mode of action. The literature changes frequently in terms of the knowledge available about drug indications and mechanisms of action, and so this information needs to be reviewed regularly.

\section{Conclusion}

The need for improved drug discovery productivity and innovation [21] [22] has led to intensifying efforts by employing advanced technologies [1] [2] [3], novel therapeutic strategies such as RNA therapeutics and monoclonal antibodies, and the knowledge of target druggability features [23], and the systems-level profiles [24] learnt from the studies of the approved and clinical trial drugs and targets. The enriched information and search facilities in TTD complement the other established drug and target databases in promoting the drug discovery research.

\section{Acknowledgements}

This work was funded by the research support of National Natural Science Foundation of China (81202459, 21505009 and 21302102); by Innovation Project on Industrial Generic Key Technologies of Chongqing (cstc2015zdcy-ztzx120003); by the Chongqing Graduate Student Research Innovation Project (CYB14027); by the Fundamental Research Funds for the Central Universities (CDJZR14468801, CDJKXB14011, 2015CDJXY).

\section{References}

[1] Hopkins, A.L. and Groom, C.R. (2002) The Druggable Genome. Nature Reviews. Drug Discovery, 1, 727-730. https://doi.org/10.1038/nrd892

[2] Imming, P., Sinning, C. and Meyer, A. (2006) Drugs, Their Targets and the Nature and Number of Drug Targets. Nature Reviews. Drug Discovery, 5, 821-834. 
https://doi.org/10.1038/nrd2132

[3] Zheng, C.J., Han, L.Y., Yap, C.W., Ji, Z.L., Cao, Z.W. and Chen, Y.Z. (2006) Therapeutic Targets: Progress of Their Exploration and Investigation of Their Characteristics. Pharmacological Reviews, 58, 259-279. https://doi.org/10.1124/pr.58.2.4

[4] Engelman, J.A., Zejnullahu, K., Mitsudomi, T., Song, Y., Hyland, C., Park, J.O., Lindeman, N., Gale, C.M., Zhao, X., Christensen, J., et al. (2007) MET Amplification Leads to Gefitinib Resistance in Lung Cancer by Activating ERBB3 Signaling. Science, 316, 1039-1043. https://doi.org/10.1126/science.1141478

[5] Chen, Z., Cheng, K., Walton, Z., Wang, Y., Ebi, H., Shimamura, T., Liu, Y., Tupper, T., Ouyang, J., Li, J., et al. (2012) A Murine Lung Cancer Co-Clinical Trial Identifies Genetic Modifiers of Therapeutic Response. Nature, 483, 613-617. https://doi.org/10.1038/nature10937

[6] Barabasi, A.L., Gulbahce, N. and Loscalzo, J. (2011) Network Medicine: A Network-Based Approach to Human Disease. Nature Reviews. Genetics, 12, 56-68. https://doi.org/10.1038/nrg2918

[7] Zhao, S. and Iyengar, R. (2012) Systems Pharmacology: Network Analysis to Identify Multiscale Mechanisms of Drug Action. Annual Review of Pharmacology and Toxicology, 52, 505-521. https://doi.org/10.1146/annurev-pharmtox-010611-134520

[8] Csermely, P., Agoston, V. and Pongor, S. (2005) The Efficiency of Multi-Target Drugs: The Network Approach Might Help Drug Design. Trends in Pharmacological Sciences, 26, 178-182. https://doi.org/10.1016/j.tips.2005.02.007

[9] Jia, J., Zhu, F., Ma, X., Cao, Z., Li, Y. and Chen, Y.Z. (2009) Mechanisms of Drug Combinations: Interaction and Network Perspectives. Nature Reviews. Drug Discovery, 8, 111-128. https://doi.org/10.1038/nrd2683

[10] Law, V., Knox, C., Djoumbou, Y., Jewison, T., Guo, A.C., Liu, Y., Maciejewski, A., Arndt, D., Wilson, M., Neveu, V., et al. (2014) DrugBank 4.0: Shedding New Light on Drug Metabolism. Nucleic Acids Research, 42, D1091-1097. https://doi.org/10.1093/nar/gkt1068

[11] Qin, C., Zhang, C., Zhu, F., Xu, F., Chen, S.Y., Zhang, P., Li, Y.H., Yang, S.Y., Wei, Y.Q., Tao, L., et al. (2014) Therapeutic Target Database Update 2014: A Resource for Targeted Therapeutics. Nucleic Acids Research, 42, D1118-1123. https://doi.org/10.1093/nar/gkt1129

[12] Pawson, A.J., Sharman, J.L., Benson, H.E., Faccenda, E., Alexander, S.P., Buneman, O.P., Davenport, A.P., McGrath, J.C., Peters, J.A., Southan, C., et al. (2014) The IUPHAR/BPS Guide to PHARMACOLOGY: An Expert-Driven Knowledgebase of Drug Targets and Their Ligands. Nucleic Acids Research, 42, D1098-1106. https://doi.org/10.1093/nar/gkt1143

[13] Bento, A.P., Gaulton, A., Hersey, A., Bellis, L.J., Chambers, J., Davies, M., Kruger, F.A., Light, Y., Mak, L., McGlinchey, S., et al. (2014) The ChEMBL Bioactivity Database: An Update. Nucleic Acids Research, 42, D1083-1090. https://doi.org/10.1093/nar/gkt1031

[14] Liu, T., Lin, Y., Wen, X., Jorissen, R.N. and Gilson, M.K. (2007) BindingDB: A Web-Accessible Database of Experimentally Determined Protein-Ligand Binding Affinities. Nucleic Acids Research, 35, D198-201. https://doi.org/10.1093/nar/gkl999

[15] Kanehisa, M., Goto, S., Sato, Y., Kawashima, M., Furumichi, M. and Tanabe, M. (2014) Data, Information, Knowledge and Principle: Back to Metabolism in KEGG. Nucleic Acids Research, 42, D199-205. https://doi.org/10.1093/nar/gkt1076

[16] Smietana, K., Siatkowski, M. and Moller, M. (2016) Trends in Clinical Success 
Rates. Nature Reviews. Drug Discovery, 15, 379-380. https://doi.org/10.1038/nrd.2016.85

[17] Yang, H., Qin, C., Li, Y.H., Tao, L., Zhou, J., Yu, C.Y., Xu, F., Chen, Z., Zhu, F. and Chen, Y.Z. (2016) Therapeutic Target Database Update 2016: Enriched Resource for Bench to Clinical Drug Target and Targeted Pathway Information. Nucleic Acids Research, 44, D1069-1074. https://doi.org/10.1093/nar/gkv1230

[18] Overington, J.P., Al-Lazikani, B. and Hopkins, A.L. (2006) How Many Drug Targets Are There? Nature Reviews. Drug Discovery, 5, 993-996. https://doi.org/10.1038/nrd2199

[19] Verstovsek, S., Kantarjian, H., Mesa, R.A., Pardanani, A.D., Cortes-Franco, J., Thomas, D.A., Estrov, Z., Fridman, J.S., Bradley, E.C., Erickson-Viitanen, S., et al. (2010) Safety and Efficacy of INCB018424, a JAK1 and JAK2 Inhibitor, in Myelofibrosis. The New England Journal of Medicine, 363, 1117-1127. https://doi.org/10.1056/NEJMoa1002028

[20] Gao, B., Doan, A. and Hybertson, B.M. (2014) The Clinical Potential of Influencing Nrf2 Signaling in Degenerative and Immunological Disorders. Clinical Pharmacology: Advances and Applications, 6, 19-34.

[21] Paul, S.M., Mytelka, D.S., Dunwiddie, C.T., Persinger, C.C., Munos, B.H., Lindborg, S.R. and Schacht, A.L. (2010) How to Improve R\&D Productivity: the Pharmaceutical Industry’s Grand Challenge. Nature Reviews. Drug Discovery, 9, 203-214. https://doi.org/10.1038/nrd3078

[22] Pammolli, F., Magazzini, L. and Riccaboni, M. (2011) The Productivity Crisis in Pharmaceutical R\&D. Nature Reviews. Drug Discovery, 10, 428-438. https://doi.org/10.1038/nrd3405

[23] Lipinski, C.A., Lombardo, F., Dominy, B.W. and Feeney, P.J. (2001) Experimental and Computational Approaches to Estimate Solubility and Permeability in Drug Discovery and Development Settings. Advanced Drug Delivery Reviews, 46, 3-26. https://doi.org/10.1016/S0169-409X(00)00129-0

[24] Zhu, F., Han, L., Zheng, C., Xie, B., Tammi, M.T., Yang, S., Wei, Y. and Chen, Y. (2009) What Are Next Generation Innovative Therapeutic Targets? Clues from Genetic, Structural, Physicochemical, and Systems Profiles of Successful Targets. The Journal of Pharmacology and Experimental Therapeutics, 330, 304-315. https://doi.org/10.1124/jpet.108.149955

Submit or recommend next manuscript to SCIRP and we will provide best service for you:

Accepting pre-submission inquiries through Email, Facebook, LinkedIn, Twitter, etc. A wide selection of journals (inclusive of 9 subjects, more than 200 journals)

Providing 24-hour high-quality service

User-friendly online submission system

Fair and swift peer-review system

Efficient typesetting and proofreading procedure

Display of the result of downloads and visits, as well as the number of cited articles

Maximum dissemination of your research work

Submit your manuscript at: http://papersubmission.scirp.org/

Or contact jbm@scirp.org 